\title{
JEKK
}

Jurnal Epidemiologi Kesehatan Komunitas

2 (1), 2017, 36-45

\section{Faktor Risiko yang Berpengaruh terhadap Kejadian HIV/AIDS pada Pengguna Napza Suntik (Studi Epidemiologi Di Kota Pontianak)}

\author{
Sumini", Suharyo hadisaputro ${ }^{* *}$, Anies $^{* * *}$, Budi Laksono ${ }^{* * * *}$, Muchlis AU Sofro ${ }^{* * * *}$ \\ "Dinas Kesehatan Kota Pontianak, ${ }^{* *}$ Politeknik Kesehatan Semarang, ${ }^{* * *}$ Fakultas Kedokteran \\ Universitas Diponegoro, ${ }^{* * * *}$ Dinas Kesehatan Provinsi Jawa Tengah ${ }^{* * * * * *}$ RSUD Dr. Kariadi Semarang
}

\begin{abstract}
Background: Injecting drug users (IDUs) are play role of high risk of HIV infection due to sexual behaviors that do not use condoms and use of unsterile needles. The high productive age group affected by HIV/AIDS and death, then the lower life expectancy, availability and productivity of the workforce. The purpose of the study proved that individual and environmental factors are risk factors for the incidence of HIV / AIDS among injecting drug users.

Method: This observational analytic study, with the design of the case control study equipped with a qualitative approach of risk factors retrospectively. The target population of the study were IDUs in Pontianak with a sample of 96 people consisting of 48 cases of HIV/AIDS and 48 were IDUs not control HIV/AIDS. The sampling method is non-probability sampling study with consecutive sampling manner. Data analysis included univariate, bivariate using chisquare test and multivariate logistic regression test.

Results: Multivariate analysis of four variables associated with the incidence of HIV/AIDS among IDUs is married status $(\mathrm{OR}=5,57)$, had sexual intercourse more than two people $(\mathrm{OR}=$ $4,13)$, frequency of injecting drugs $>6$ time / week yet $(\mathrm{OR}=3,71)$, and not / do not work (OR $=3,28)$
\end{abstract}

Conclusion: Risk factors were shown to influence: the married status, had sexual intercourse more than $\geq 2$ people, frequency of injecting drugs $>6$ times / week and not/do not work yet.

Keywords: HIV/AIDS; IDUs; risk factors

Penulis korespondensi : sumini7111@gmail.com 


\section{Pendahuluan}

HIV (Human Immunodeficiency Virus) adalah virus yang menyerang sistem kekebalan tubuh sehingga tubuh rentan terhadap berbagai penyakit, seperti TB, TORCH dan lain-lain. AIDS (Acquired Immune Deficiency Syndrom) yaitu terminologi sindrom (tahap klinis akhir dari infeksi HIV) karena kehilangan imunitas seluler. AIDS adalah penyakit retrovirus yang disebabkan oleh virus HIV ditandai dengan menurunnya sistem kekebalan tubuh khususnya menyerang limfosit $\mathrm{T}$ serta menurunnya jumlah CD4 yang bertugas melawan infeksi. Jumlah CD4 menurun hingga kurang dari 200 sel per $\mu \mathrm{L}$ darah atau $14 \%$ dari seluruh limfosit tanpa memperhatikan status klinis. Jumlah CD4 normal yaitu $400-1200$ sel per $\mu \mathrm{L}$ darah. ${ }^{1-4}$ Efek jangka panjang pada aspek demografi karena tingginya proporsi kelompok umur produktif yang lebih muda terkena penyakit HIV/AIDS (78,3\%) dan kematian yang tinggi maka menurunkan angka harapan hidup, ketersediaan dan produktifitas angkatan kerja. ${ }^{4-6}$ Tujuan Milenium Pembangunan 2015 menunjukkan harapan baru untuk strategi pencegahan yang efektif dan pengendalian infeksi HIV di seluruh dunia, yaitu target 'nol infeksi HIV, nol kematian dan nol deskriminasi terkait AIDS'.

Kelompok kunci yang berisiko tinggi yaitu perilaku seksual yang tidak menggunakan kondom dan penggunaan jarum suntik yang tidak steril pada pengguna napza suntik (penasun). HIV dapat menyebar dengan cepat setelah memasuki komunitas pengguna napza suntik. Populasi penasun diperkirakan $0,2-0,5 \%$ dari populasi dunia dan lebih dari $45 \%$ terinfeksi baru HIV. Penasun dan pasangan seksual mereka tercatat 68\% infeksi baru di Negara Iran (rentang perkiraan 57-78\%), di Negara Eropa Timur sebesar $40 \%$ dan $36 \%$ di Philipina. ${ }^{8}$ Prevalensi HIV pada orang yang menyuntik narkoba sangat tinggi diantara populasi umum. Hasil survei pada penasun di Afrika, prevalensi HIV sangat tinggi di Afrika Selatan sebesar 12,4\% dan 42,9\% di Kenya, hal ini disebabkan karena meningkatnya penggunaan obat heroin di sub Sahara Afrika.

Di Indonesia kumulatif kasus HIVAIDS tahun 1987 sampai dengan 31 Maret 2014 sebanyak 134.042 kasus HIV dan AIDS 54.231 kasus. Infeksi baru HIV terjadi kenaikan yaitu tahun 2012 sebanyak 21.511 kasus menjadi 29.037 kasus pada tahun 2013, dan kasus pada bulan Januari-Maret 2014 sebanyak 6.626 kasus. Kasus AIDS terjadi penurunan tahun 2012 sebanyak 8,747 kasus menjadi 6.266 kasus pada tahun 2013, dan bulan Januari-Maret 2014 sebanyak 308 kasus. Jumlah kasus kematian akibat AIDS terus meningkat hingga tahun 2012 mencapai 1.489 kasus, dan tahun 2013 terjadi penurunan menjadi 726 kasus, dan pada bulan Januari-Maret 2014 sebanyak 30 kasus. Angka kematian (CFR) AIDS menurun dari $18,5 \%$ pada tahun 2010 menjadi $12,9 \%$ pada tahun $2013 .{ }^{9}$

Provinsi Kalimantan Barat prevalensi HIV AIDS sebesar 38,65/100.000 penduduk urutan ke lima setelah Papua $(357,03)$, Papua Barat $(226,32)$, Bali $(104,74)$ dan DKI Jakarta $(77,82) .{ }^{9}$ Data kumulatif kasus HIV tahun 2014 sebesar 4.290 kasus, terdiri laki-laki 2.839 kasus dan perempuan 1.451 kasus, sedangkan AIDS sebanyak 1.699 kasus terdiri dari 1.326 kasus laki-laki dan 373 kasus pada perempuan. Estimasi IDU tahun 2014 sebesar 506 orang, menduduki urutan kedua tertinggi setelah WPS (wanita penjaja seks) dan sebesar $(52 \%)$ terdapat di Kota Pontianak. ${ }^{(10)}$ Estimasi komunitas pengguna napza suntik di Kota Pontianak sebanyak 237 orang.

Hasil Survei Terpadu Biologis dan Perilaku (STBP) pada tahun 2013 di Kota Pontianak ditemukan 112 orang menunjukan reaktif virus HIV dari 183 responden. Tingginya pengguna napza suntik di Kota Pontianak yang berisiko menularkan virus HIV melalui perilaku berbagi jarum suntik dan perilaku seksual maka strategi pengendalian yang dapat dilakukan adalah meningkatkan sosialisasi pencegahan penularan pada IDU dan pengurangan dampak buruk pada penyalahguna napza suntik (IDU). ${ }^{1,7}$ Data pengguna Layanan alat suntik steril (LASS) bulan maret 2014 sebanyak 49 penasun jarum dan kondom 
terdistribusi sebanyak 539 buah.

Dari uraian diatas maka tujuan penelitian yaitu membuktikan umur pertama menggunakan napza suntik, jenis kelamin, tingkat pendidikan, status pekerjaan, status perkawinan, status penggunaan jenis napza suntik, lama menggunakan napza suntik, konsistensi berbagi jarum suntik, frekuensi menyuntik napza, konsistensi menggunakan wadah melarutkan napza bersama, perilaku jumlah pasangan seksual, konsistensi menggunakan kondom, keberadaan tato dan keberadaan tindik berpengaruh terhadap kejadian HIV/AIDS pada pengguna napza suntik.

\section{Metode}

Populasi penasun 237 orang terdiri 109 orang dengan HIV/AIDS dan 118 orang tidak HIV/AIDS. Populasi penelitian homogen yaitu populasi kasus dan kontrol adalah penasun. Jumlah sampel penelitian sebesar 96 orang terdiri 48 kasus IDU HIV positif dan 48 kontrol IDU dengan HIV negatif diketahui sejak awal penelitian kemudian diteliti secara retrospektif faktor risiko yang berpengaruh terhadap kejadian HIV/AIDS pada IDU. Pengambilan sampel menggunakan metode non probability sampling dengan cara consecutive sampling.

Pendekatan kualitatif menggunakan pendekatan campuran sekuensial yaitu penelitian analitik observasional, dengan desain penelitian kasus kontrol yang dilengkapi dengan pendekatan kualitatif untuk mempertegas hasil analisis kuantitatif. Pengumpulan data menggunakan kuesioner terstruktur, wawancara medalam dilakukan setelah analisis kuantitatif. ${ }^{12,13}$

Analisis data meliputi analisis univariat untukmengetahui d e s kri ps i variabel penelitian, analisis bivariat menggunakan uji chi-square tabel $2 \times 2$ dan analisis multivariat menggunakan uji regresi logistic untuk menganalisis hubungan beberapa variabel secara bersama-sama untuk melihat besar pengaruh variabel independen terhadap kejadian HIV AIDS pada IDU. ${ }^{13}$

\section{Hasil}

\section{Analisis Bivariat}

Penelitian dilakukan pada 96 responden terdiri dari kelompok kasus 48 orang dan kelompok kontrol 48 orang.

Gambaran populasi studi yaitu responden yang memanfaatkan LASS $(72,9 \%)$, membersihkan jarum suntik menggunkan alkohol dan pemutih (57,3\%). Umur responden pertama menggunakan napza suntik rata-rata 22 tahun, termuda usia 19 tahun dan tertua 31 tahun baik pada kasus maupun kontrol. Umur $<20$ tahun pertama menggunakan napza suntik terbanyak pada kelompok kasus (25,0\%), 100\% laki-laki dengan tingkat pendidikan rendah terbanyak pada kelompok kasus (37,5\%) sedangkan kelompok kontrol terbanyak tingkat pendidikan tinggi (72,9\%).

Responden dengan status menikah dan tidak bekerja terbanyak pada kelompok kontrol masing-masing $62,5 \%$. Jenis napza yang sering digunakan adalah heroin lebih banyak pada kelompok kasus sebanyak $97,9 \%$, lama menggunakan napza suntik $>5$ tahun terbanyak pada kelompok kasus $(95,8 \%)$. IDU berbagi jarum suntik terbanyak pada kelompok kasus $(91,7 \%)$ frekuensi menyuntik $>6 \mathrm{kali} / \mathrm{minggu}$ sebanyak $68,8 \%$. Perilaku hubungan seksual dengnn $\geq 2$ orang yang berbeda dan tidak konsisten menggunkan kondom terbanyak pada kelompok kontrol $(93,8 \%)$. Sebagian besar responden memiliki tato dan tindik bagian tubuh.

Berdasarkan tabel 1 diketahui bahwa faktor risiko yang terbukti berpengaruh terhadap kejadian HIV/AIDS pada pengguna napza suntik yaitu IDU berstatus tidak bekerja sebesar 3,33 lebih mungkin terjadi HIV AIDS ( $p=0,004$; OR 3.33; 95\%CI1.44-7.70), IDU berstatus menikah sebesar 2,54 lebih mungkin terjadi HIV AIDS ( $p=0,025$; OR 2.54; 95\%CI 1.125.79), IDU menyuntik napza $>6 \mathrm{kali} / \mathrm{minggu}$ sebesar 4,02 lebih mungkin terjadi HIV AIDS ( $\mathrm{p}=0,001$; OR 4.02 ; 95\%CI 1.714.38), IDU menggunakan napza $>5$ tahun sebesar 5,31 lebih mungkin terjadi HIV 
AIDS $(\mathrm{p}=0,025$; OR $5.31 ; 95 \%$ CI 1.08 26.04), IDU yang melakukan hubungan seksual dengan jumlah pasangan $\geq 2$ orang sebesar 2,36 lebih mungkin terjadi HIV AIDS ( $p=0,040$; OR 2.36 ; 95\%CI 1.035.40) dan tidak konsisten menggunakan kondom dengan nilai $\mathrm{p}=0,003$.

\section{Analisis Multivariat}

Variabelbebas yang layak di ikutsertakan dalam analisis multivariat adalah variabel yang memiliki kemaknaan secara statistik dengan nilai $\mathrm{p}=<0,25$. Analisis multivariat yang digunakan adalah regresi logistik berganda karena variabel terikatnya adalah variabel kategorik dikhotom. ${ }^{14}$

Berdasarkan Tabel 2 diketahui bahwa terdapat empat variabel yang terbukti secara statistik berpengaruh terhadap kejadian HIV/AIDS pada pengguna napza suntik (IDU), yaitu IDU yang berstatus menikah sebesar 5,57 lebih mungkin untuk terjadi HIV AIDS (OR $=5,57 p=0,005$; 95\%CI 1,6618,74), "IDU menikah aktif melakukan seks tetapi ya kadang kepingin itu waktu lagi diluar, biasenye si kalau abis pakau (pakai putaw) same same kawan 2-3 kali sebulan ya bisejugajajan seks 2-3 kalisebulan"
IDU yang melakukan hubungan seksual dengan jumlah pasangan $\geq 2$ orang sebesar 4,13 untuk terjadi HIV AIDS $(\mathrm{OR}=4,13 p=0,018 ; 95 \% \mathrm{CI} 1,28-13,30)$, "kalau bis pakau kadang ada pengaruhnya keinginan melakukan hubungan seks, mencari pasangan lain dengan PSK atau pacar".

IDU menyuntik napza $>6 \mathrm{kali} / \mathrm{minggu}$ sebesar 3,71 lebih mungkin terjadi HIV AIDS $(\mathrm{OR}=3,71 p=0,030 ; 95 \% \mathrm{CI} 1,13$ 12,16) dan IDU yang tidak/belum bekerja sebesar 3,28 lebih mungkin terjadi HIV AIDS $(\mathrm{OR}=3,28 p=0,039 ; 95 \% \mathrm{CI} 1,06$ 10,15).

Probabilitas kejadian HIV/AIDS pada IDU dihitung menggunakan persamaan regresi logistik berikut :

$$
\begin{aligned}
\mathrm{p} & =\frac{1}{1+\mathrm{e}^{(a+b 111,1,62 \times 2+\ldots . . b k \times k 2)}} \\
& =\frac{1}{1+\mathrm{e}^{-[-4,663+1,7181+1,41811,3111+1,190(1)]}} \\
& =\frac{1}{1+0,37757} \\
& =72,6 \%
\end{aligned}
$$

\begin{tabular}{|c|c|c|c|c|c|c|c|c|}
\hline \multirow{2}{*}{ No. } & \multirow{2}{*}{ Variabel } & \multicolumn{2}{|c|}{ Kasus } & \multicolumn{2}{|c|}{ Kontrol } & \multirow{2}{*}{ OR } & \multirow{2}{*}{$95 \% \mathrm{CI}$} & \multirow{2}{*}{$p$} \\
\hline & & $\mathrm{n}$ & $\%$ & $\mathrm{n}$ & $\%$ & & & \\
\hline
\end{tabular}

Tabel 1. Faktor risiko yang berpengaruh terhadap kejadian HIV/AIDS pada pengguna napza suntik (penasun) di Kota Pontianak

1. Umur pertama menggunakan napza suntik

$\begin{array}{llllllll}<20 \text { tahun } & 12 & 25,0 & 10 & 20,8 & 1,26 & 0,49-3,29 & 0,627 \\ >20 \text { tahun } & 36 & 75,0 & 38 & 79,2 & & & \end{array}$

2. Jenis Kelamin

Laki-laki

Perempuan

3. Tingkat pendidikan

$<9$ tahun (rendah)

$>9$ tahun (tinggi)

4. Status pekerjaan

Tidak Bekerja

Bekerja

$\begin{array}{rrrrrrr}48 & 100,0 & 48 & 100,0 & 1,61 & 0,68-3,83 & 0,275 \\ 0 & 0,0 & 0 & 0,0 & & & \end{array}$

$\begin{array}{llll}18 & 37,5 & 13 & 27,1\end{array}$

$3,33 \quad 1,44-7,70 \quad 0,004 *$

$\begin{array}{llll}30 & 62,5 & 35 & 72,9\end{array}$ 


\begin{tabular}{lllllllll}
\hline \multirow{2}{*}{ No. } & \multirow{2}{*}{ Variabel } & \multicolumn{2}{c}{ Kasus } & \multicolumn{2}{c}{ Kontrol } & \multirow{2}{*}{ OR } & \multirow{2}{*}{$95 \% \mathrm{CI}$} & $\mathrm{p}$ \\
\cline { 3 - 6 } & $\mathrm{n}$ & $\mathrm{n}$ & $\%$ & $\mathrm{n}$ & $\%$ & & & \\
\hline
\end{tabular}

5. Status Perkawinan

\section{Menikah}

Tidak/belum menikah

6. Jenis napza yang digunakan

Heroin/putaw

Amfetamin/shabu-shabu

7. Lama menggunakan

napza suntik

$$
\begin{aligned}
& >5 \text { tahun } \\
& <5 \text { tahun }
\end{aligned}
$$

8. Konsistensi berbagi jarum suntik

$$
\begin{aligned}
& \text { Ya (sering+kadang+ } \\
& \text { Tidak pernah }
\end{aligned}
$$

9. Frekuensi menyuntik napza

$>6 \mathrm{kali} / \mathrm{minggu}$

$<6 \mathrm{kali} / \mathrm{minggu}$

10. Konsistensi menggunakan wadah untuk melarutkan napza bersama

Ya (kadang+sering+selalu) Tidak pernah

11. Perilaku jumlah pasangan seksual

$$
\begin{aligned}
& \geq 2 \text { orang } \\
& 1 \text { orang }
\end{aligned}
$$

12. Tidak konsistensi menggunakan kondom

Tidak pernah Ya (kadang+sering+selalu)

13. Keberadaan tato

Memiliki

Tidak memiliki

14. Keberadaan tindik

Memiliki

Tidak memiliki

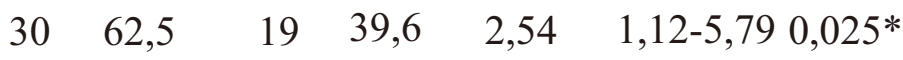

$$
\begin{aligned}
& \begin{array}{llll}
18 & 37,5 & 29 & 60,4
\end{array}
\end{aligned}
$$

$\begin{array}{lllllll}47 & 97,9 & 43 & 89,6 & 5,46 & 0,61-48,66 & 0,204\end{array}$

$\begin{array}{llll}1 & 2,1 & 5 & 10,4\end{array}$

$$
\begin{array}{rrrrrrr}
46 & 95,8 & 39 & 81,3 & 5,31 & 1,08-26,04 & 0,204 \\
2 & 4,2 & 9 & 18,8
\end{array}
$$

$$
\begin{array}{rrrrrrr}
44 & 91,7 & 38 & 79,2 & & & \\
4 & 8,3 & 10 & 20,8 & 2,89 & 0,84-9,98 & 0,083
\end{array}
$$$$
33 \quad 68,8 \quad 17 \quad 35,4 \quad 4,02 \quad 1,71-4,38 \quad 0,001 *
$$$$
15 \quad 31,2 \quad 31 \quad 64,6
$$ 


\begin{tabular}{llcrr}
\hline No. & \multicolumn{1}{c}{ Variabel Penelitian } & p & \multicolumn{1}{c}{ OR } & \multicolumn{1}{c}{$95 \% \mathrm{CI}$} \\
\hline 3. & Status tidak bekerja & 0,004 & 3,33 & $1,44-7,70$ \\
4. & Status menikah & 0,025 & 2,54 & $1,12-5,79$ \\
5. & Menggunakan napza suntik $>5$ tahun & 0,025 & 5,31 & $1.08-26,04$ \\
6. & Perilaku jumlah pasangan seksual $\geq 2$ orang & 0,040 & 2,36 & $1,03-5,40$ \\
7. & Memiliki tato & 0,066 & 2,14 & $0,94-4,83$ \\
8. & Konsistens berbagi jarum suntik & 0,083 & 2,89 & $0,84-9,98$ \\
9. & Konsistens menggunakan wadah untuk & 0,159 & 3,93 & $0,77-19,98$ \\
& melarutkan napza bersama & & & \\
10. & Memiliki tindik & 0,181 & 2,08 & $0,70-6,18$ \\
11. Jenis heroin/putaw napza yang digunakan & 0,204 & 5,46 & $0,61-48,66$ \\
\hline
\end{tabular}

Tabel 3. Variabel model akhir dengan analisis regresi logistik

\begin{tabular}{clrrrr}
\hline No. & \multicolumn{1}{c}{ Variabel Independent } & $\mathrm{B}$ & $\mathrm{p}$ & $\mathrm{Exp}(\mathrm{B})$ & \multicolumn{1}{c}{$95 \% \mathrm{CI}$} \\
\hline 1. & Status menikah & 1,718 & 0,005 & 5,57 & $1,66-18,74$ \\
2. & Jumlah pasangan seksual $>=2$ org & 1,418 & 0,018 & 4,13 & $1,28-13,30$ \\
3. & Frekuensi menyuntik napza $>6$ & 1,311 & 0,030 & 3,71 & $1,13-12,16$ \\
& kali/minggu & & & & \\
4. & Status tidak bekerja & 1,190 & 0,039 & 3,28 & $1,06-10,15$ \\
& Constanta & $-4,663$ & 0,001 & 0,009 & \\
\hline
\end{tabular}

Tabel 4. Rangkuman distribusi status perkawinan dengan beberapa variabel bebas berpengaruh terhadap kejadian HIV AIDS pada IDU

\begin{tabular}{rlr}
\hline No. & \multicolumn{1}{c}{ Variabel Penelitian } & Distribusi \\
\hline 1. & Status menikah menggunakan jenis napza heroin & $95,9 \%$ \\
& Status menikah menggunakan jenis napza shabu-shabu & $4,1 \%$ \\
\hline 2. & Status menikah lama menggunakan napza suntik $>5$ tahun & $89,8 \%$ \\
& Status menikah lama menggunakan napza suntik $\leq 5$ tahun & $10,2 \%$ \\
3. & Status menikah konsistens berbagi jarum suntik (ya+kadang-kadang) & $85,7 \%$ \\
\hline & Status menikah tidak pernah berbagi jarum suntik & $14,3 \%$ \\
4. & Status menikah tidak konsisten/tidak pernah menggunakan kondom & $73,5 \%$ \\
& Status menikah konsisten menggunakan kondom & $26,5 \%$ \\
\hline 5. & Status menikah memiliki tato & $53,1 \%$ \\
& Status menikah tidak memiliki tato & $46,9 \%$ \\
\hline 6. & Status menikah memiliki tindik & $79,6 \%$ \\
& Status menikah tidak memiliki tindik & $20,4 \%$ \\
\hline
\end{tabular}

\section{Pembahasan}

IDU status menikah berpeluang berisiko tertular virus HIV serta menularkan kepada pasangannnya karena perilaku penggunaan napza suntik, berbagi jarum dan perilaku jumlah pasangan seksual tidak tetap tanpa menggunakan kondom. Penelitian ini sesuai dengan penelitian Perngmark et al, IDU yang menikah memiliki peluang terjadinya HIV/AIDS sebesar 2,4 kali dibandingkan dengan tidak menikah (OR 


\section{$2.37 ; 95 \%$ CI $1.20-4.73) .^{15}$}

Berdasarkan penelitian Wang et al, IDU dengan status menikah berpengaruh terhadap kejadian HIV/AIDS dengan nilai $\mathrm{p}<0,001 .{ }^{16}$ IDU yang telah menikah ditemukan $89 \%$ aktif melakukan hubungan seksual dalam 6 bulan terakhir dengan istri / pacar, dan 95\% hubungan melalui vagina tanpa menggunakan kondom. ${ }^{16}$ Hal ini menggambarkan bahwa transmisi seksual yang tidak aman merupakan pola transmisi utama terjadinya HIV/AIDS. Hasil penelitian ditemukan sebesar $62,5 \%$ pengguna napza suntik yang berstatus menikah terjadi HIV/AIDS lebih besar dibandingkan dengan yang tidak terjadi HIV/AIDS sebesar 39,6\%. IDU status menikah proporsi terbanyak menggunakan jenis napza heroin $(95,9 \%)$, lama menggunakan napza suntik $>5$ tahun $(89,8 \%)$, konsisten berbagi jarum suntik $(85,7 \%)$, tidak pernah menggunakan kondom $(73,5 \%)$, memiliki tato $(53,1 \%)$ dan memiliki tindik $(79,6 \%)$. Prediksi status menikah terbukti berpengaruh terhadap kejadian HIV AIDS pada pengguna napza suntik dipengaruhi oleh beberapa faktor tersebut. Status hubungan seks pada pasangan, berisiko terjadinya infeksi HIV. Pelanggan pekerja seks yang telah menikah maka berisiko tertular dari pelanggan seksnya, juga berisiko menularkan pada pasangan tetap. ${ }^{15}$ Sejalan dengan penelitian Moccoy, et al bagi IDU yang telah menikah memiliki jumlah pasangan seksual $>2$ orang sehingga memiliki peluang untuk terjadinya HIV sebesar 1,4 kali dibandingkan yang belum menikah $(\mathrm{OR}=1.43 ; 95 \% \mathrm{CI}=1,13$; 1.82: $\mathrm{p}=0,003)$. $^{17}$

IDU dengan status menikah karena pengaruh menyuntik napza di luar rumah sehingga IDU mencari pasangan lain dengan pacar atau PSK yang dapat dilakukan 2-3 kali sebulan, tanpa menggunakan kondom. IDU yang melakukan hubungan seksual dengan $\geq$ 2 orang yang berbeda berisiko terjadi HIV/AIDS pada kelompok pola perilaku homoseksual dan heteroseksual. Perilaku seksual merupakan penyebab utama infeksi HIV di dunia ${ }^{(18)}$ Sesuai dengan penelitian Moccoy et al jumlah pasangan seks $>2$ orang berpeluang terjadi HIV/AIDS sebesar 1.43
$(95 \% \mathrm{CI} ; 1,13-1,82) \mathrm{p}=0.003,{ }^{17}$ dan Alex jumlah pasangan seks enam bulan terakhir hasil analisis bivariat OR 1,02 (95\% CI; 1,01-1,03) dan multivariat diperoleh OR 1,002 (95\% CI;1,000-1,004). ${ }^{19}$ Berdasarkan temuan Perngmark et al IDU yang melakukan hubungan seks terakhir dengan pekerja seks tanpa menggunakan kondom sebesar $78 \% .^{15}$ Pengguna narkoba melakukan seks aktif berisiko terinfeksi HIV dihubungkan dengan beberapa pasangan seks yaitu 8 dari 10 pengguna narkoba seksual aktif mendorong melakukan seks dalam 30 hari terakhir tanpa kondom, sehingga terjadi penyebaran infeksi HIV diantara penggunan napza. ${ }^{20}$ Menurut Matos IDU yang mabok minum alkohol delapan kali lebih mungkin untuk berhubungan seks dengan PSK (OR 8,0 95\% CI: 2,2, 29,2) dan hampir tiga kali lebih mungkin berhubungan seks dengan pacar (OR 2,8; 95\%CI: 1.2, 6.4). dan enam kali lebih mungkin untuk bertukar seks untuk memperoleh uang atau obat $(\mathrm{OR}=$ 6,0, 95\% CI: 1,5, 24,5). ${ }^{21}$ IDU cenderung melakukan hubungan seksual dengan pasangan tidak tetap karena pengaruh memakai napza di luar rumah sehingga mencari pasangan lain yaitu dengan PSK atau pacar. Sejalan dengan penelitian Hien et $a l$, sebagian besar IDU melakukan hubungan seksual pertama kali berumur kurang dari 20 tahun dan 4 minggu terakhir melakukan dengan WPS. ${ }^{22}$

Hasil survei USAID menunjukan sebagian besar penasun mengindikasikan memiliki pasangan seksual dalam waktu yang sama dan memiliki banyak pasangan yang memiliki latar belakang risiko berbeda. Dua karakteristik tersebut mempercepat terjadinya penularan HIV dari kelompok penasun ke kelompok lainnya baik risiko tinggi maupun risiko rendah. ${ }^{23}$ IDU menyuntik napza $>6$ kali seminggu berisiko sebesar 3,71 kali terjadi HIV/AIDS dibandingkan dengan tidak HIV/AIDS. Frekuensi menyuntik napza berisiko terjadi HIV AIDS karena luka bekas tusukan jarum suntik menjadi tempat masuknya virus HIV apabila kontak dengan darah yang mengandung virus HIV.

Sejalan dengan penelitian Josep et al frekuensi menyuntik obat yang tinggi, 
memiliki peluang terjadi HIV/AIDS sebesar 1,3 kali (multivariat OR $=1,26-1,92, p$ $<0,05) .{ }^{25}$ Menurut Moccoy frekuensi menyuntik dalam sebulan 1-30 kali mempunyai peluang sebesar 1.67 kali $(95 \%$ CI;1.33，2.10) $\mathrm{p}<0.0001$ sedangkan frekuensi menyuntik $>30$ kali memiliki peluang sebesar 3.25 kali (95\% CI: 2.66, 3.97) $\mathrm{p}<0.0001$ dan selalu menyuntik setiap waktu berpeluang sebesar $9.81 \mathrm{kali}$ $(95 \% \mathrm{CI} ; 6.07,15.9) \mathrm{p}<0.0001 .^{17,24}$

Rata-rata penasun menyuntik napza dalam satu minggu sebanyak 5 hari, dengan frekuensi penyuntikan rata-rata berkisar antara 2-3 kali per hari. Frekuensi menyuntik dipengaruhi oleh penggunaan jenis napza. Berdasarkan temuan David et al frekuensi menyuntik jenis kokain dalam 30 hari sebanyak 80-119 kali. Responden yang pernah menyuntik bubuk kokain sebesar $21,4 \%$ dari 89 sampel, lebih banyak dibandingkan kelompok yang tidak pernah sebesar $18,0 \%$ dari 89 sampel dengan nilai COR 2.36 (1.09- 5.10) dan AOR 2.81 (1.16$6,80) .{ }^{25}$ Penasun yang menyuntik $>120$ lebih banyak pada responden yang pernah menyuntik bubuk kokain sebesar $46.1 \%$ dan yang belum pernah $31.8 \%$ dengan nilai AOR 3.13 (1.45- 6.74): Frekuensi menyuntik pada pengguna kokain lebih tinggi per bulan ratarata 104 suntikan atau sekitar 3,5 perhari dibandingkan penasun jenis lain sebanyak 78 suntikan atau 2.6 suntikan per hari. ${ }^{26}$ Tetapi hasil penelitian ini bertentangan dengan penelitian Perngmark bahwa frekuensi menyuntik napza 6 bulan terakhir 2-3 kali per hari tidak berhubungan dengan infeksi HIV dengan nilai $\mathrm{p}=0,153$; OR 2,$06 ; 95 \% \mathrm{CI}$ $0,75-5,66{ }^{15}$

Frekuensi responden menyuntik napza $>6$ kali seminggu atau 1,6 kali/hari bahwa frekuensi menyuntik napza di Kota Pontianak dipengaruhi oleh jenis dan lama menggunakan napza suntik serta dampak yang timbul akibat putus zat menuntut IDU menyuntikan napza kembali untuk menghilangkan rasa sakit. ${ }^{27}$ Jenis napza yang sering digunakan adalah heroin/putaw merupakan golongan dengan tingkat ketergantungan yang sangat tinggi sehingga mempengaruhi frekuensi penyuntikan. Sesuai dengan temuan Hien yaitu opium/heroin digunakan lebih dari 10 tahun $(78,7 \%)$ lebih banyak menyuntik di tempat membeli napza dan menyuntik 2 kali atau lebih $(78 \%)^{28}$

IDU yang tidak bekerja berisiko untuk terjadi HIV/AIDS sebesar 3,28 kali dibandingkan dengan tidak HIV/AIDS karena lebih mungkin untuk berbagi jarum suntik. Hal ini sesuai dengan penelitian Wang et al, IDU yang tidak/belum bekerja berhubungan dengan kejadian HIV/AIDS. dengan nilai $\mathrm{p}<0,00$, hal ini terkait dengan konsistensi pemakaian jarum suntik tidak steril. IDU yang tidak/belum bekerja kemungkinan untuk berbagi jarum suntik dalam 6 bulan terakhir sebesar $75 \%$ lebih besar dibandingkan dengan yang bekerja dengan nilai $p<0,001 .{ }^{16}$ Penelitian di Uzbaikistan, penasun yang tidak bekerja secara signifikan terinfeksi HIV lebih tinggi dibandingkan dengan yang bekerja $(p=0,02)$. Hal ini sesuai dengan kasus HIV pada penasun bahwa kasus terbanyak terjadi pada golongan umur 15-24 tahun (usia sekolah). ${ }^{29}$

IDU tidak dapat bekerja karena tidak mempunyai keahlian, tidak dapat produktif akibat pemakaian napza serta stigma dari masyarakat yang menggagap bahwa kelompok IDU merupakan sampah masyarakat terkait dengan perilaku yang bertentangan dengan norma yang ada dimasyarakat dan norma agama. Sejalan dengan penelitian David et al, terbukti bahwa IDU yang seropositif HIV pada orang yang mempunyai riwayat tunawisma 2,5 kali lebih rendah untuk berhenti berbagi jarum suntik dan berbagi tempat/ perlengkapan melarutkan obat. ${ }^{26}$

Faktor yang tidak terbukti berpengaruh terhadap kejadian HIV/AIDS pada pengguna napza suntik karena penelitian dilakukan pada populasi yang homogen yaitu populasi kasus dan kontrol adalah pengguna napza suntik (penasun). Faktor yang tidak terbukti berpengaruh seperti : status penggunaan jenis napza suntik heroin, proporsi pada kelompok kasus dan kontrol merata karena populasi penelitian adalah pengguna napza suntik (penasun). Faktor risiko responden yang menggunakan napza $>5$ tahun sebesar $92,9 \%$ dan sebesar $72,9 \%$ tidak konsisten berbagi jarum suntik, 
tidak terbukti berpengaruh karena responden memanfaatkan layanan alat suntik steril (LASS). Tidak konsisten menggunakan kondom saat hubungan seksual dengan pasangan lain tidak terbukti berpengaruh karena populasi studi homogen yaitu kelompok kasus dan kontrol adalah pengguna napza suntik (penasun). Keberadaan tato dan keberadaan tindik juga tidak terbukti berpengaruh terhadap kejadian HIV/AIDS pada pengguna napza suntik karena lebih dari $80 \%$ jarum yang digunakan untuk membuat tato dan tindik telah dibersihkan terlebih dahulu menggunakan alkohol.

\section{Kesimpulan}

Faktor risiko yang terbukti berpengaruh terhadap kejadian HIV/AIDS pada pengguna napza suntik yaitu status IDU menikah, berperilaku memiliki jumlah pasangan $\geq 2$ orang, menyuntik napza $>6$ kali, status tidak bekerja IDU yang menikah cenderung berbagi jarum suntik dan telah menggunakan napza $>5$ tahun serta tidak menggunakan kondom saat berhubungan seks dengan pasangan lain, yang dapat dilakukan 2-3 kali dalam sebulan karena dipengaruhi penggunaan napza diluar rumah (di spot). Frekuensi menyuntik napza di pengaruhi oleh jenis napza haroin yang di pakai, dan pengaruh pemakaian napza suntik ditempat membeli napza cenderung IDU mencari pasangan lain dengan PSK atau pacar.

\section{Ucapan Terimakasih}

Terimakasih kepada pihak Dinas Kesehatan Kota Pontianak, Yayasan Pontianak Plus dan pasien HIV AIDS penasun yang telah membantu proses pengumpulan data.

\section{Daftar Pustaka}

1. James, C. 2006. Manual Pemberantasan Penyakit Menular, Ed 17, penterjemah Kandun I N. Cetakan II. Jakarta: Infomedika. pp. 1-11

2. Kathy, Stolley, Glass J. 2009. HIV/AIDS.
California: Greenwood Publishing Group. pp. 1-25.

3. Brashers, V.,L. 2008. Aplikasi Klinis Patofisiologi Pemeriksaan dan Manajemen, Bab 27 Penyakit HIV. Jakarta: EGC.pp.389-393.

4. Nasronudin. 2007HIV/AIDS; Pendekatan Biologi Molekuler, Klinis dan Sosial. Surabaya: Airlangga Universitas Press. pp. $1-130$

5. Ridwan A. 2012. Kebijakan dan Respon Epidemik Penyakit Menular, Bab 8, Epidemiologi Penularan HIV dan AIDS pada Populasi Berisiko, Cetakan Pertama. Bogor: IPB Press. pp. 133-156.

6. BNN UI. 2008. Laporan Survei Penyalahgunaan Narkoba di Indonesia: Studi Kerugian Ekonomi dan Sosial Akibat Narkoba,. Jakarta: BNN.

KementrianKesehatanRI.2012.Reporbn

7. The Achievement of The Millennium Goals Development Indonesia. Jakarta.

8. UNAIDS. 2013. Report on The Global AIDS Epidemic,. Geneva: WHO.

9. Kementrian Kesehatan RI. 2012. Statistik HIV/AIDS Indonesia. Jakarta :P2PL

10. Kementerian Kesehatan.

Dinas Kesehatan Provinsi Kalimantan Barat. 2014. Laporan Kasus HIV /AIDS Triwulan II.

11. Stanley, L., Janella, K.1997. Besar Sampel dalam Penelitian Kesehatan. Yogyakarta: UGM Press. pp. 2-29.

12. Armenian, HK. 2009. The Case Control Method; Design and Applications. New York: Oxford University Press. pp.

13. 17-29. Pendekatan Kualitatif, Kuantitatif dan Mixed,edisi ketiga. Yogyakarta: Pustaka Pelajar. pp.305-335.

14. Riyanto A. 2012. Penerapan Analisis Multivariat dalam Penelitian Kesehatan, Yogyakarta: Nuha Medika.pp.1-55.

15. Perngmark P,Celentano D D, Kawichai. 2003. Risk factors for HIV Infection among Drug Injectors in Southern Thailand. 1999 / 2000 Drug and Alcohol Dependence 71. pp. 229- 238.

16. Wang H, Li G, Brown K, Smith K, Jin X, Dong R, Wang N. 2011. The Cha- 
racteristics and Risk Factors for HIV Infection among Beijing Drug User in Different Settings. J Drug and Alcohol Dependence. pp. 37-45.

17. Mccoy CRB, Lai S, Metsch L, Messiah S, Zhao W. 2004. Injection Drug Use and Crack Cocaine Smoking: Independent and Dual Risk Behaviors for HIV Infection. Sciene Direct. Ann Epidemiol; 14. pp. 535-542.

18. Elsevier. 2008. Global HIV/AIDS Medicine. China: Elsevier.

Kral HA, Rizky BN, Lorvick J, Lauren G, Bacchetti P, Brian ER. 2001. Sex ual Transmission of HIV-1 Injection Drug Users in San Francisco. USA: Risk Factor Analysis. Lancet; 357. pp. 1397-1401.

20. Booth ER, Kwiatkowski FC, Citwood DD. 2000. Sex Related HIV Risk Behaviors Diferential Risks among Injection Drug Users, Crack, Smokers and Injection Drug Users Who Smoke Crack. Drug and Alcohol Dependence 58 . pp. 219-226.

21. Matos DT, Rables RR, Sahai H, Colon $\mathrm{MH}$, Reyes CJ, Marrero A, et al. 2004. HIV Risk Behaviors and Alcohol Intozication among Injection Drug Users in Puerto Rico. Drug and Alcohol Dependence 76. pp. 229-234.

22. Hien T.N, Giang T L, Phan N B. Deville W,. Ameijden E J.C, Wolffers I. 2001. Risk Factors Of HIV Infection and Needle Sharing Among Injecting Drug Users, Journal of Substance Abuse 13. pp. $45-58$.

23. USAID. 2011. Upaya Mendukung Penanggulangan HIV/AIDS Manual untuk Organisasi Masyarakat Sipil Pengguna Napza Suntik In press.
24 Celentano DD, Munoz, Chon S, Vlahov D. 2001. Dynamics of Behavior Risk Factor for HIV/AIDS Study of Injection Drug Users. Drug and Alcohol Dependent; 61. pp. 315-322. Joseph T.F, Tsui H Y, Zhang Y, Cheng F, Zhang L, Zhang J, et al. 2008.

25. Comparing HIV Related SyiringeSharing Behavior among Female IDU Engaging Versus Not Engaging in Comercial Sex. Elsevier Ireland Ltd. 2008. Drug and Alcohol Dependence 97. pp. 54-63.

David B, Janet A T, Susan S, Mark K, 26. Robert H, Merrill S. 2005. Demografic, HIV Risk Behavior, and Health Status Characteristik of "Crack" Cocain Injectors Compare to Injection Druguser Un Three New Angland Cities. Drug and Alkohol Dependent 81. pp. 221-229.

27. Juniarta IW, Setiawan M, Gordon JD, Desembriartista YE, Hadi N, Bahrul A, et al. 2001. Pedoman Mengurangi Dampak Buruk Narkoba di Asia, Edis Indonesia. pp. 334-335.

28. Lin TY, Vincent C, Hui LC. 2013. Prevalence, Correlates, and Risk Perception of HIV Infection Among Heroin Users in Central Taiwan. Sciene Direct.

29. Sanchez JL, Todd CS, Bautista CT, Botros B AE Khakimov MM, Guzal M. Giyasova GM, et a1. 2006. High HIV Prevalence and Risk Factors among Injection Drug Users in Tashkent, Uzbekistan, 2003-2004. J Drug and Alcohol Dependence ;82 (susspl 1). pp.814-822. 